\title{
The Influence of Imperfect Film Moral Values on Society Regarding Body Shaming Problems in the Digital Era
}

\author{
Risa Muarifah \\ risa.muarifah-2020@,fib.unair.ac.id \\ Mirasantika Insafilillah \\ mirasantika.insafilillah-2020@fib.unair.ac.id \\ Pricelia Primareta \\ pricelia.primareta-2020@fib.unair.ac.id
}

Corresponding Author: Dr. Moses Glorino Rumambo Pandin, M.Si., M.Phil./moses.glorino@,fib.unair.ac.id

\begin{abstract}
Airlangga University - B Campus, Jl. Dharmawangsa Dalam, Airlangga Gubeng, Surabaya City, East Java 60286. Phone(031) 5035676
\end{abstract}

\begin{abstract}
In this digital era, body shaming is increasingly prevalent on social media. Body shaming is the behavior of giving negative comments about a person's physical condition. Meanwhile, film is one of the mass media that is used as a medium of entertainment, information, and education to the public. In this case, we, the authors, examine the influence of the moral values of imperfect films on people's views in the digital era. The methods we use are observational methods and literacy studies. The result of this research is a film, especially in this case, imperfect films can be able to introduce or educate the public about the issue of body shaming that occurs in life in the digital era. The suggestion from this research is that the film industry in Indonesia should be more advanced in making positive works that can inspire and educate the public.
\end{abstract}

Key words : film, body shaming, social media. 


\section{INTRODUCTION}

Today, the standard of beauty in women still applies in the life of Indonesian society. Women who are considered to have an unattractive appearance often receive humiliation from society or become victims of body shaming. Fredricson and Robert (1997) explain that body shaming is a form of behavior of self and others towards the internalization of ideal beauty standards. Meanwhile, according to Gilbert (2007) body shaming is an attitude or behavior towards weight, body size and appearance of self and others. In this digital era, the act of body shaming is increasingly widespread and we often ecounter it on social media than in real life because social media can cover a wider area and more people.

One of the acts of body shaming was experienced by a public figure, namely Aurel Hermansyah on his Instagram account @aurelie.hermansyah. The eldest daughter of singer Anang Hermansyah received a lot of comments and criticism from netizens when she is pregnant. When Aurel uploaded a photo of herself, an account named @sylaishaxxxx commented, "So fat, gosh I'm shocked but still cute" and an account called@annisaxxxxx9x also added a comment, "How come his chin is like that, it's so sharp". Acts of body shaming such as this example can affect the mental health and lives of victims.

In 2019, an Indonesian film titled Imperfect was released, directed by Ernest Prakasa. This film raises the problem of body shaming that occurs in everyday life, Jessica Mila as the main character who experiences various injustices just because of her physical condition. Currently, the film is a very popular entertainment media or favored by the public. In addition, film is also used as a medium of education and information because it often raises a problem and reality that occurs in real life. So, the film Imperfect indirectly has played a role in introducing the issue of body shaming to the community as well as providing education in the form of moral messages to the community.

Research on body shaming has also previously been carried out by Melati and Amalia (2021) in their research article entitled "Semiotics of Roland Barthes in Body Shaming Analysis Research on the Imperfect Film". This study describes the analysis of signs of body shaming in the film Imperfect using Roland Barthes' semiotics. The result of this research is that there are meanings of denotation, connotation, and myth from the film Imperfect. The denotative meaning 
that shows the body shaming action can be seen from the actions and dialogues carried out by several characters to the victims of body shaming actions. In the film Imperfect, the researcher also found several signs that indicate the acts of body shaming that are carried out verbally and non-verbally and have hidden meanings in them. The meaning of myth often appears in the film Imperfect as a woman is seen as beautiful when she has white and clean skin. The similarities between this study and ours also discuss the issue of body shaming. The difference is, the study only explains the signs of body shaming in the film Imperfect. What has not been found in this research is the effect of moral messages regarding body shaming contained in the film Imperfect on society in the digital era.

The purpose of this study is to determine the effect of moral messages in imperfect films that can change people's views and actions regarding the issue of body shaming in the digital era. The benefit of this research is to provide inspiration for the Indonesian film industry to be more active in creating positive works that can inspire and educate the public.

Based on the background described above, several formulations of the problem can be drawn as follows:

1. What are the moral messages in imperfect films related to body shaming?

2. How can the influence of moral messages in imperfect films change people's views and actions regarding body shaming in the digital era?

\section{METHOD}

The approach used in this research is a qualitative approach which will produce data in the form of sentences or narratives. The source of the data used comes from the results of interviews via google form which is distributed in the form of a questionnaire with a population of 30 respondents. Data was collected by means of observation by distributing questionnaires and by studying literature from several references. Then, the data were analyzed using qualitative data analysis techniques.

Activity implementation diagram: 


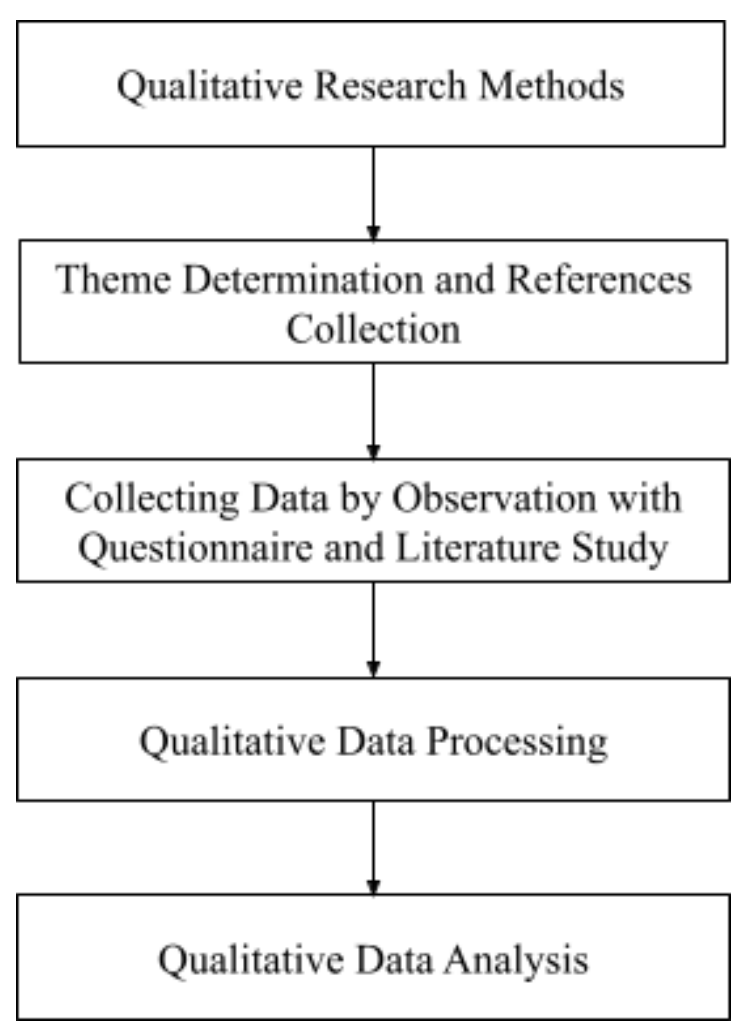

\section{RESULTS}

Our questionnaire has been successfully filled by 30 people. All respondents are in the age group 17-20 years. Based on occupation, all respondents are students and they are also social media users. Based on whether the respondents really understand what body shaming is in general, 24 people (80\%) are very understanding, and 6 people $(20 \%)$ other respondents are quite understanding. Based on whether the respondents have seen or found any acts of body shaming on social media, 26 people (86.6\%) of the respondents have seen it, while 4 people $(13.3 \%)$ of the other respondents have never seen or found any acts of body shaming on social media. Media.

Observation result :

\begin{tabular}{|l|c|c|c|}
\hline Understanding of body shaming & Good & Enough & Bad \\
\hline Respondents who have seen the film & 18 & 2 & - \\
\hline Respondents who have not seen the film & 8 & 2 & - \\
\hline
\end{tabular}




\begin{tabular}{|l|c|c|c|}
\hline Understanding of the impact of body shaming & Good & Enough & Bad \\
\hline Respondents who have seen the film & 20 & - & - \\
\hline Respondents who have not seen the film & 7 & 2 & 1 \\
\hline
\end{tabular}

The results of our literacy study are based on the results of research conducted by Yessi Febrianti and Kusnul Fitria (2019) entitled "The Meaning and Attitudes of Body Shaming Behavior in Social Media (A Digital Ethnographic Study on Instagram". The research was conducted by interviewing five informants who are victims of body shaming on Instagram. As victims of body shaming behavior, the five informants in this study were Intan, a journalist at an online media in Indonesia, Meira, an author of a book entitled "I'm Perfect", Arbida a student from Yogyakarta and Diyan, a private employee who works in advertising and Rhisma, who comes from the city of flowers, is shown by frequently getting body shaming comments on their Instagram, which shows that body shaming on social media is more common than in the real world.

\section{DISCUSSION}

Based on the research results obtained, in the digital era body shaming is more common on social media than in real life. In Indonesia, the perpetrators of body shaming are increasing, along with the increase in the number of internet users, especially social media (Yenny, 2019). One of the things that causes body shaming cases on social media to occur more often than in the real world is anonymity. Anonymity on social media is a strong reason for netizens to make sarcastic comments without worrying about their identity being known (Yenny, 2019).

Based on research conducted by Eva Nur Rachmah and Fahyuni Baharuddin (2019) with the title "Factors of Body Shaming Behavior in Social Media", there are several factors that shape body shaming on social media according to the narrative of body shaming actors, namely, body shaming is a common thing., depending on the acceptance of each subject, and constructive criticism. In addition, there is also cultural influence and the presence of artists as 
role models. Other factors are feeling jealous of other people's luck, fad, driving away boredom, and having an anonymous account so that you feel more free to comment on other people.

The film Imperfect made by Ernest Prakasa is also a recording of the reality that grows and develops in society along with the rise of cases of body shaming. This film indirectly wants to give a moral message regarding body shaming and change people's perception of the standard of a woman's beauty.

The film Imperfect was very well received by the wider community. The content in the film is very touching the hearts of the audience. Not only that, the moral values conveyed through this film are also very beneficial for people who suffer the same fate as Rara (the victim of body shaming) in the film. Here are the moral values contained in the film Imperfect :

- Be grateful for the body that God has given us. Turn insecurity into gratitude..

God has created us that way. As we know, no human is perfect. Humans are created with their own strengths and weaknesses. But what is always a topic of conversation is a person's shortcomings, such as a body shape that is not ideal. But it is important for us to remain grateful for the shape of the body we have today.

- There is no need for standards to call women beautiful, because all women have their own beauty.

"Beautiful" is a word every woman wants to hear. But unfortunately the word is still difficult to express by the public regarding the high standard of beauty or commonly referred to as "good looking women." In fact, to mention the word "beautiful" does not need a standard. Because every woman has her own beauty and a different face.

- If you meet other people, don't talk about their physique.

It is important for us not to talk about our physique or body shape when we meet other people. Because that person doesn't necessarily want to talk about it. So it's better if we don't do that and look for other topics of discussion, like what he's busy with now, stories about fun things, etc.

- Parents should not do body shaming to their own children.

Being insulted by the closest people like friends is already painful, what about being insulted by your own parents? For children, parents are the number one support system and it is the job of parents to always support their children. However, if parents 
also insult the child's body shape, this will greatly affect the child's mental and psychic abilities.

\section{- The importance of choosing an environment that has positive energy.}

If we are in a positive environment, the support we get will also be positive and will also affect our love for our bodies and the emergence of a body positivity mindset. Body positivity is where an individual instills a positive mindset or mindset that everyone including himself deserves to have a positive view of his own body, regardless of how society and cultural views or trends towards the 'ideal' body are.

In the digital era, films are not only used as a medium of entertainment, but also as a media of information and education. As communication, films are an important part of the system used by individuals and groups to send and receive messages (Sumarno, 1996). Films always influence and shape society based on the message behind it without ever acting otherwise. Films always record the reality that grows and develops in society and then projects it on the screen. Essentially and substantially, films have power that will have implications for community communication. The moral message conveyed in the film will indirectly have an influence on the community.

Film is one of the mass media of mass communication, so the role and function of the film itself is the same as the role and function of mass communication, which can be used as a means of disseminating information about events in the environment, both outside and within society. Film is also a mirror or window of the society where the mass media is located so that the values, norms, and lifestyles that apply to society will be presented in the films produced. However, films also influence attitudes by reinforcing, creating, and changing norms if the film is watched repeatedly. In this case, watching movies is the behavior of using media which can be seen from the frequency of watching movies and the types of movies watched.

Media films build our knowledge of social issues and have a significant influence on how we respond to problems. We cannot deny that film media has a great contribution in shaping our way of thinking. So it is clear that film media also plays an important role in how we react to life. 
' From the results of the research that we have done, the percentage of understanding about the meaning and impact of body shaming on respondents who have watched the imperfect film is higher than those who have not watched the imperfect film. This is because respondents who have watched the imperfect learn about the issue of body shaming through the main character in the film who experiences body shaming. People who have watched the film indirectly try to understand what the main character feels and grow a sense of caring for the realities that actually happen in life. Thus, we can conclude that imperfect films have an influence on people's views about body shaming.

\section{CONCLUSION}

Based on the discussion, it can be concluded that the existence of the film Imperfect which raises the issue of body shaming that is currently rife in society can have an influence on people's views about body shaming. The moral message conveyed through the film Imperfect indirectly provides an understanding of the issue of body shaming to the audience, so that the audience will stop body shaming against others. Therefore, through its moral messages, the film Imperfect can be useful for overcoming the problem of body shaming in today's digital era. 


\section{REFERENCES}

Alini, A., \& Meisyalla, L. N. (2021). Gambaran Kejadian Body Shaming dan Konsep Diri pada Remaja di SMKN 1 Kuok. PREPOTIF: Jurnal Kesehatan Masyarakat, 5(2), 1170-1179.

Angelina, P. dkk. (2021). Gambaran Self-Esteem Remaja Perempuan yang Merasa Imperfect Akibat Body Shaming. Jurnal Experientia, 9(2), 94-103.

Anggaaraini., \& Gunawan, B. I. (2019). Upaya Hukum Penghinaan (Body Shaming) di Kalangan Media Sosial Menurut Hukum Pidana dan UU ITE. Jurnal Lex Justitia, 1(2), 113-123.

Anisa, A. R., \& Winduwati, S. (2021). Pemaknaan Body Positivity dalam Film Imperfect pada Kalangan Remaja di Jakarta. Koneksi, 5(2), 427-433.

Aprilia, R., Sriati, A., \& Hendrawati, S. (2020). Tingkat kecanduan media sosial pada remaja. Journal of Nursing Care, 3(1).

Atsila, R. I., Satriani, I., \& Adinugraha, Y. (2021). Perilaku Body Shaming dan Dampak Psikologis pada Mahasiswa Kota Bogor. KOMUNIKATIF: Jurnal Ilmiah Komunikasi, 10(1), 84-101.

Ayuningsari, P. N. A. (2021). Promosi Perpustakaan Melalui Konten Visual Di Dinas Kearsipan Dan Perpustakaan Kabupaten Trenggalek (Produk Film Pendek) (Doctoral dissertation, Universitas Airlangga).

Diputra, R., \& Nuraeni, Y. (2021). Analisis Semiotika dan Pesan Moral pada Film Imperfect 2019 Karya Ernest Prakasa. Jurnal Purnama Berazam, 2(2), 111-122.

Darusman, Y. M., \& Benazir, D. M. (2021). Penyuluhan Pentingnya Pemahaman Tentang Kemanfaatan Dan Kemudaratan Media Sosial Di Desa Kawunglarang, Kecamatan Rancah, Kabupaten Ciamis. Jurnal Lokabmas Kreatif: Loyalitas Kreatifitas Abdi Masyarakat Kreatif, 2(2), 68-74.

Febrianti, Y. \& Fitria, K. (2020). Pemaknaan dan Sikap Perilaku Body Shaming di Media Sosial (Sebuah Studi Etnografi Digital di Instagram. Jurnal Media dan Komunikasi, 3(1), 12-25.

Firmansyah, R. A., \& Wrastari, A. T. (2014). Pengaruh Penggunaan Film Sebagai Media Belajar Terhadap Pencapaian Higher Order Thinking Skill pada Mahasiswa Fakultas Psikologi UNAIR. Jurnal Psikologi Klinis dan Kesehatan Mental, 3(1), 40-47.

Gani, A. W., \& Jalal, N. M. (2021). Persepsi Remaja Tentang Body Shaming. Jurnal IKRA-ITH Humaniora, 5(2), 155-161. 
Hana, D. R., \& Suwarti. (2019). Dampak Psikologis Peserta Didik yang Menjadi Korban Cyber Bullying. PSISULA : Prosiding Berkala Psikologi, 1, 20-28.

Hidayat, R., Malfasari, E., \& Herniyanti, R. (2019). Hubungan perlakuan body shaming dengan citra diri mahasiswa. Jurnal Keperawatan Jiwa, 7(1), 79.

Iswari, D., Hartini, N., \& Unair, F. P. (2005). Pengaruh pelatihan dan evaluasi self-talk terhadap penurunan tingkat body-dissatisfaction. Journal Unair Surabaya, 7(3), 2310-7945.

Kurniawati, S. (2020). Dinamika Psikologis dan Motivasi Belajar Siswa yang Mengalami Body Shaming di SD Ma'arif Ponorogo. Doctoral dissertation. IAIN PONOROGO.

Kusumastuti, W. (2021). Pesan Moral pada Film Imperfect (Analisis Wacana Teun A. Van Dijk). Skripsi. IAIN PONOROGO.

Laksono, S. A. (2018). Hubungan Warna Kulit dengan Citra Tubuh dan Harga Diri Mahasiswa di Fakultas Keperawatan Universitas Airlangga (Doctoral dissertation, Universitas Airlangga).

Lestari, S. (2019). Bullying or Body Shaming? Young Women in Patient Body Dysmorphic Disorder. PHILANTHROPY: Journal of Psychology, 3(1), 59-66.

Maharani, dkk. (2020). Pengaruh Isi Pesan Stop Body Shaming pada Sikap Followers Terhadap Body Shaming. Jurnal Pustaka Komunikasi, 3(1), 112-122.

Manting, M. D., \& Djuwita, A. (2021). Semiotika Roland Barthes dalam Penelitian Analisis Body Shaming pada Film Imperfect. e-Proceeding of Management, 8(4), 4142-4148.

McMahon, J., McGannon, K. R., \& Palmer, C. (2021). Body shaming and associated practices as abuse: athletes entourage as perpetrators of abuse. Sport, Education and Society, 1-14.

Micheal, M., \& Azeharie, S. S. (2020). Perlawanan Penyintas Body Shaming Melalui Media Sosial. Koneksi, 4(1), 138-146..

Maulina, C. M. (2020). Frekuensi Kemunculan Pesan Sosial Dalam Film Drama Komedi Indonesia (Analisis Isi Film Imperfect: Karier, Cinta, \& Timbangan Karya Ernest Prakasa (Doctoral dissertation, Universitas Muhammadiyah Malang).

Mudjiono, Y. (2020). Kajian Semiotika dalam Film. Jurnal Ilmu Komunikasi, 1(1), 125-138.

Mutmainnah, A. N. (2020). Analisis Yuridis Terhadap Pelaku Penghinaan Citra Tubuh (Body Shaming) dalam Hukum Pidana di Indonesia. Jurnal Ilmiah Ilmu Hukum, 26(8), 975-987.

Ndruru, M. K., dkk. (2020). Pengaturan Hukum Tentang Tindakan Penghinaan Citra Tubuh (Body Shaming). Jurnal Tectum LPPM Universitas Asahan, 1(2), 288-295. 
Pahlawani, P. A. (2019). Gambaran Pengelolaan Stress Pada Laki-laki Usia Remaja Madya Yang Mengalami Body Shaming (Doctoral dissertation, Universitas Airlangga).

Pamuji, W. H. (2020). TA: Penulisan Skenario dalam Pembuatan Film Pendek Bergenre Drama dengan Tema Gangguan Kesehatan Mental yang Berupa "Self-Harm" (Doctoral dissertation, Universitas Dinamika).

Pricilia, C., \& Yoanita, D. (2019). Pengaruh Bodily Shame di Instagram terhadap Konsep Diri Remaja Perempuan. Jurnal e-Komunikasi, 7(2).

Puluhulawa, M. R., \& Husain, R. (2021). Body Shaming Through Social Media as a Digital Crime in the Era of Disruption. Jalrev: Jambura Law Review, 3(1), 112-123.

Puspitasari, S. T. (2019). Upaya Peningkatan Body Acceptance Melalui Gerakan Say No to Body Shaming di Kalangan Pelajar Mojokerto. Jurnal Pelayanan Kepada Masyarakat, 1(2), 110-119.

Rachmah, E., \& Baharuddin, F. (2019). Faktor Pembentuk Perilaku Body Shaming Di Media Sosial. In Prosiding Seminar Nasional \& Call Paper Psikologi Sosial, 66-73.

Ramadhani, D. W., \& Ms, R. I. (2021, August). Pertanggungjawaban Pidana Terhadap Pelaku Penghinaan Citra Tubuh (Body Shaming) Di Media Sosial (Studi Putusan Nomor 882/Pid. Sus/2019/PN. Jkt. Brt). In Proceeding of Conference on Law and Social Studies.

Ramadhani, M. R., \& Pratama, A. R. I. (2020). Analisis Kesadaran Cyber Security Pada Pengguna Media Sosial Di Indonesia. AUTOMATA, 1(2).

Rizkiyah, I., \& Apsari, N. C. (2019). Strategi Coping Perempuan Terhadap Standardisasi Cantik di Masyarakat. Marwah: Jurnal Perempuan, Agama, dan Jender, 18(2), 133-152.

Rohmadoni, Z. V., dkk. (2021). Psikoedukasi untuk Penanganan Body Shaming. Jurnal Pustaka Mitra, 1(1), 39-42.

Rusli, A. (2021). Analisis Sosio-Yuridis Terhadap Perlindungan Hukum Korban Penghinaan Citra Tubuh (Body Shaming) Melalui Media Sosial= Socio-Yuridic Analysis Of Legal Protection Of Victims Of Body Shaming Through Social Media (Doctoral dissertation, Universitas Hasanuddin).

Septiani, E. (2020). Pengaruh Penyuluhan Film dan Leaflet Terhadap Keikutsertaan Pemeriksaan Inspeksi Visual Asam Asetat (IVA) di Puskesmas Pasarwajo. Midwifery Journal: Jurnal Kebidanan UM. Mataram, 5(1), 29-38. 
Sukmawati, A., \& Kumala, A. P. B. (2020). Dampak Cyberbullying pada Remaja di Media Sosial. Alauddin Scientific Journal of Nursing, 1(1), 55-65.

Trisnasari, L. (2020). Pesan Moral dalam Film Yowis Ben (Analisis Semiotika Dalam Film Karya Bayu Skak) (Doctoral dissertation, Universitas Muhammadiyah Malang).

Wati, D. K., \& Sumarmi, S. (2017). Citra tubuh pada remaja perempuan gemuk dan tidak gemuk: Studi cross sectional. Amerta Nutrition, 1(4), 398-405.

Wekke, Ismail dkk. (2019). Metode Penelitian Sosial. Yogyakarta: Penerbit gawe Buku..

Wisnuwardhani, A. (2021). Body Shaming Di Kalangan Mahasiswi (Studi Tentang Makna Body Shaming Bagi Mahasiswi Sebagai Korban Body Shaming Di Kota Surabaya) (Doctoral dissertation, Universitas Airlangga).

Yenny. \& Astuti, S. W. (2019). Body Shaming di Dunia Maya: Studi Netnografi pada Akun Youtube Rahmawati Kekeyi Putri Cantika. Promedia, 5(1), 166-188.

Yusuf, R. N., Musyadad, V. F., Iskandar, Y. Z., \& Widiawati, D. (2021). Implikasi Asumsi Konsep Diri Dalam Pembelajaran Orang Dewasa. Edukatif: Jurnal Ilmu Pendidikan, 3(4), 1144-1151.

Zainiya, M. A., \& Aesthetika, N. M. (2022). Analisis Semiotika John Fiske Tentang Body Shaming dalam Film Imperfect. Indonesian Journal of Cultural and Community Development, 11(1), 6-13. 